DOI https://doi.org/10.30525/978-9934-26-113-8-43

\title{
ГІГІСНІЧНА ОЦІНКА ЗАБЕЗПЕЧЕНОСТІ МІСЬКИХ ТА СІЛЬСЬКИХ ЗАКЛАДІВ ЗАГАЛЬНОЇ СЕРЕДНЬОЇ ОСВІТИ УКРАЇНИ ПРИРОДНИМ ОСВІТЛЕННЯМ ТА ІНСОЛЯЦІЕЮ
}

\author{
Махнюк В. М. \\ доктор медичних наук, \\ стариий науковий співробітник, \\ лікар вищої кваліфікаиійної категорії \\ за спеціальністю «Загальна гігієна»,
} завідувач лабораторії гігієни планування та забудови населених місиь Державна установа «Інститут громадського здоров'я імені О. М. Марзєєва Начіональної академії медичних наук Украӥни»

\section{Павленко Н. П.}

кандидат біологічних наук,

старший науковий співробітник лабораторії гігієни планування та забудови населених місиь

Державна установа «Інститут громадського здоров'я імені О. М. Марзєєва Національної академії медичних наук України»

\section{Могильный С. М.}

кандидат біологічних наук,

старший науковий співробітник лабораторії гігієни планування та забудови населених місиь Державна установа «Інститут громадського здоров'я імені О. М. Марзєєва Наџіональної академії медичних наук України» м. Київ, Україна

Навчання дітей у закладах загальної середньої освіти (33СО) супроводжується психоемоційним, зоровим та статичним навантаженням, створюваним навчальним процесом, з використанням візуальноелектронних пристроїв та умовами перебування тривалий час у спорудах шкіл. Разом 3 тим, діти постійно перебувають під впливом містобудівного оточення: глухі паркани, гладкі двері, підземні переходи та багатоповерхові будинки 3 великою кількістю вікон, стіни 3 облицюванням кахельною плиткою, що створює гомогенні та агресивні поля, погіршує умови для відпочинку органу зору та сприйняття 
предметів у вуличному просторі, які значно віддалені від них [1, с. 198-234]

В умовах сучасної щільної забудови сельбищної території населених пунктів за містобудівними нормами допускається зменшувати на 15-25\% площу земельних ділянок для будівництва шкіл, що в подальшому не дає можливості розмістити необхідний набір приміщень у будівлі школи 3 дотриманням відповідних нормативних санітарно-гігієнічних умов. Зменшення площ земельних ділянок забудови шкільних об'єктів у міських умовах створюють погіршення планувальних рішень приміщень у 33СО. Збільшення глибини класних приміщень за умов зменшення стін з світлоотворами, розміщення рекреаційних зон у закритому коридорному просторі, де відсутнє природне освітлення, значно погіршує умови забезпечення природним освітленням робочих місць школярів та місць їх прогулянок і ігор.

На думку деяких авторів несприятливий вплив сучасного технологічного прогресу в процесі навчання, що характеризується перевантаженням інформаційними технологіями та перебуванням школярів в умовах вимушеного постійного використання штучного освітлення в закритих приміщеннях, особливо в осінньо-зимовий період, призводить до надмірного зорового і психологічного навантаження дітей молодшого шкільного віку з подальшим виникненням порушень стану їх здоров'я, в першу чергу зі сторони нервової системи та органу зору [2].

За даними лікарів захворюваність дітей на короткозорість збільшується саме при їх перебуванні в ускладнених умовах світлового режиму. В умовах 33СО у дітей виникає вимушена робоча поза, тобто наближення очей до об'єкта, що розглядається при читанні, письмі та малюванні, для збільшення його кутових розмірів за недостатності освітлення. При такій неправильній позі упродовж навчання за період здобуття освіти у початковій школі виникає i розвивається короткозорість у дітей.

Тому вагоме значення при гігієнічній оцінці умов навчання має показник освітленості. За роки навчання школярі саме за допомогою зорового аналізатору сприймають весь об'єм інформації, який за останні 10 років зріс у 10 разів у порівнянні з попереднім періодом. 3 огляду на зазначене, нормативи природного освітлення приміщень для 3ЗСО є суворішими i за «Санітарним регламентом для закладів загальної середньої освіти» та Державними будівельними нормами «Заклади освіти. ДБН В. 2.2-3:2018», передбачають обов'язкове дотримання: лівостороннього освітлення з КПО на рівні 2,5\%. 
У вказаній роботі було досліджено дотримання умов інсоляції та коефіцієнту природного освітлення (КПО) у 42 проектах будівництва 33СО, з них 25 міських та 17 сільських $33 \mathrm{CO}$ шляхом розрахунків, які були проведені за методиками ДБН В.2.5-28:2018 «Природне і штучне освітлення» та «Настанови 3 розрахунку інсоляції об'єктів цивільного призначення. ДСТУ-Н Б В.2.2.-27:2010».

За проведеною санітарно-гігієнічною оцінкою проектів будівництва З3СО щодо забезпечення умов інсоляції в них було встановлено, що орієнтація класних приміщень запроектованих міських та сільських 33СО за сторонами світу мала наступний розподіл: у 6,7\% проектів на північний схід; у 26,6\% - на схід; у $16,6 \%$ - на південний схід; у $10,3 \%$ - на південь; у 26,5\% - на північний захід; у 13,3\% - на північ.

Аналіз дотримання умов природного освітлення у класних приміщеннях досліджуваних нами З3СО показав, що нормативне КПО мали лише $30 \%$ шкіл, а у $70 \%$ він не забезпечувався. Відповідно нормативний КПО дотримувався у 75\% міських та у 93\% сільських 33СО. За проведеними розрахунками КПО у приміщеннях для 1-4 класів встановлено, що нормативний коефіцієнт був у $89 \%$ приміщень для перших класів міських шкіл та у 100\% сільських шкіл. У других класах даний показник відповідав нормі у $84 \%$ міських та у $97 \%$ сільських 33СО. Навчальні приміщення четвертих класів забезпечувались нормативним КПО у $82 \%$ міських та у $98 \%$ сільських 33 СО.

Основними причинами зменшення рівня КПО, який визначали у розрахунковій точці III ряду парт від вікна (на відстані в 1 м від протилежної стіни від вікна), були: наближення школи до інших будівель; недотримання нормативу глибини приміщень у 6 м; зменшення розмірів вікон до 1,6×1,4 м (норма 2,2×2,0 м). При цьому були випадки, коли приміщення освітлювались віддзеркаленим світлом та другим світлом через облаштований зимовий сад, що суперечить санітарним та будівельним нормам.

За даними протоколів натурних досліджень природного освітлення у існуючих 27 33СО (14 міських та 13 сільських 33СО), які були надані Державними установами Київський міський лабораторний центр МОЗ України та Вінницький лабораторний центр МОЗ України було встановлено, що КПО дотримувався у 63,6\% міських та 91\% сільських 3ЗСО.

Давно відомий факт, що для існування людини життєво необхідною умовою $є$ сонячне світло [3, С. 154-161]. Найбільш чутливою категорією населення до інсоляції є діти. При недостатності сонячного опромінення організм дитини втрачає рівновагу і в ньому починають відбуватись 
порушення вітамінного балансу, ослаблення захисних сил організму імунітету, загострення хронічних захворювань, розвиток рахіту у дітей та світлове голодування.

За нашими розрахунками тривалості інсоляції у навчальних приміщеннях було встановлено, що у класах тривалість інсоляції у нормативний час 3 години дотримувалась у $26,7 \%$ міських та у $16,3 \%$ сільських 33 С. При розрахунку тривалості інсоляції за класами було виявлено, що тривалість інсоляції у нормативний час дотримувалась: у навчальних приміщеннях перших класів у $84 \%$ міських та 96\% сільських 33СО; у других відповідно, 79\% та 92\%; у третіх - 87\% та $97 \%$; у четвертих $-85 \%$ та $94 \%$.

Тривалість інсоляції спортивних та ігрових майданчиків дотримувалась у $71 \%$ міських та 93\% сільських $33 \mathrm{CO}$.

Таким чином, умови інсоляції та природного освітлення не дотримувались у З3СО через ущільнення міської території, зменшенні розмірів світлопрозорих отворів, відсутність земельних ділянок потрібного розміру, що потребувало відповідного корегування на етапі проектування.

\section{Література:}

1. Нові гігієнічні підходи до сучасного містобудування в Україні. Монографія / В.М. Махнюк, С.А. Сердюк, В.В. Чорна, С.С. Гаркавий, В.Е. Лаптєв / За заг. редакцією акад. НАМН України А.М. Сердюка та редакцією чл.-кор. НАМН України Н.С. Польки. - К. : Міжрегіональний видавничий центр «Медінформ», 2021. С.198-234.

2. Бережімо очі з малечку або поради щодо гігієни зору // Практика управління закладом освіти. 2017. № 10. Режим доступу: https://edirshkoly.mcfr.ua/593902.

3. Яригін А.В., Павленко Н.П. Обгрунтування безпечності біологічного впливу інсоляції за бактерицидною, еритемною, тепловою та психоемоційною дією в житлових і громадських приміщеннях // Гігієна населених місиь : зб. наук. пр. К., 2015. Вип. 65. С. 154-161. 